\title{
The food trade in the Baltic region: the place and role of Russia, 2013-2018
}

\author{
Svetlana Yurievna Kornekova ${ }^{1, *}$,and Dmitry Evgenievich Makhnovsky ${ }^{2}$ \\ ${ }^{1}$ St. Petersburg State University of Economics, Associate Professor of the Department of regional economics and nature management \\ (REIP) doctor of geographical sciences, Saint-Petersburg, Russia \\ ${ }^{2}$ St. Petersburg State University of Economics, Assistant Professor of the Department of egional Economics and nature management \\ (REIP), Candidate of Economic Sciences, Saint-Petersburg, Russia
}

\begin{abstract}
The article discusses the dynamics of export and import of food products of the Baltic region in 2013-2018. It is stated that the introduction of a ban on the import of agricultural and food products to Russia in August 2014 had a negative impact on trade and economic relations between the Russian Federation and other countries of the Baltic region. It is hoped that the crisis period in the relationship will end, and as in the days of the Hanseatic League, countries will be able to establish a dialogue and resume mutually beneficial trade relations.
\end{abstract}

\section{Introduction}

As known, one of the key factors that contributed to the lucrative trade of the medieval cities of the Hanseatic League was access to the Baltic Sea. Nowadays this factor plays an important role in the international economic integration.

The trade and transport-logistics development of the North-West, as one of the "supporting regions" of Russia, is considered in the context of the accelerated integration of the country into the global market. The growth of the trade balance with the countries of the Baltic region can strengthen the functions of the NorthWest of the Russian Federation as a national "window adapter" to the global market and the developer in relation to the rest of the country. Unfortunately, the real facts show many difficulties and contradictions in the development of trade relations.

The purpose of this article is to consider the dynamics and characteristics of the export and import of food from countries with access to the Baltic Sea and the main strategies currently being implemented by food exporters to Russia.

At present, the territories that make up the Baltic region are not clearly defined. A number of resources by Russian authors [12] in the Baltic region include Denmark, Sweden, Finland, the Baltic countries, the German lands of Mecklenburg-Western Pomerania and Schleswig-Holstein, Warmia-Mazury, Pomerania and West Pomerania provinces of Poland, and also parts of the Russian Federation, such as St. Petersburg, Leningrad, Pskov, Novgorod and Kaliningrad regions.

The author of this article used a structural-functional approach to the research of the spatial and temporal characteristics of food supply for population; contextual, institutional and system analysis; and comparativegeographical and historical methods.

The information base of the research includes legislative acts regulating various aspects of life activity affecting food supply, state statistics, in particular, to analyze the dynamics and structure of food product turnover between the Russian Federation and other countries of the Baltic region. The data are freely available on the official website of the Federal Customs Service [2].

\section{Results}

Food trade is one of the key segments of world trade, estimated at about 2 trillion. US dollars. It is food that constitutes an important part of exports, imports and domestic freight traffic of many states, first of all, those that are distinguished by diverse natural conditions, multi-ethnic and multi-religious composition of the population [7, 12-15]. Stable food supply, meeting the needs of the population in food is a socially significant issue, so regular monitoring of the situation, analysis of causal relationships can provide a systematic study of emerging problems $[3,4,10]$.

The condition of the Russian food market, its "pain points", especially related to the need to develop deeper processing of agricultural raw materials and the production of high value-added products, have been thoroughly analyzed in numerous publications. Therefore, the author limited himself to an analysis of food trade in the Baltic region with an emphasis on the place and role of Russia. To analyze the dynamics and structure of food turnover between the Russian Federation and other countries of the Baltic region, were

\footnotetext{
* Corresponding author: kafedra reg-ec@mail.ru
} 
Table 1. The volume of food imports to the Russian Federation.

\begin{tabular}{|c|c|c|c|c|c|c|c|}
\hline \multirow{2}{*}{ Country } & \multicolumn{6}{|c|}{ Export, mln. \$ US } & \multirow{2}{*}{$\begin{array}{l}\text { The change in the } \\
\text { volume of export } \\
2018 \text { / } 2013 \text { years }\end{array}$} \\
\hline & 2013 & 2014 & 2015 & 2016 & 2017 & 2018 & \\
\hline Denmark & 65 & 96 & 65 & 70 & 70 & 53 & $-18 \%$ \\
\hline Germany & 169 & 200 & 133 & 150 & 159 & 127 & $-25 \%$ \\
\hline Estonia & 25 & 20 & 18 & 25 & 19 & 14 & $-45 \%$ \\
\hline Lithuania & 178 & 135 & 136 & 141 & 124 & 82 & $-54 \%$ \\
\hline Latvia & 216 & 291 & 249 & 277 & 277 & 308 & $43 \%$ \\
\hline Poland & 76 & 154 & 137 & 94 & 84 & 88 & $16 \%$ \\
\hline Finland & 67 & 78 & 68 & 49 & 57 & 44 & $-35 \%$ \\
\hline Sweden & 37 & 37 & 21 & 22 & 25 & 21 & $-42 \%$ \\
\hline $\begin{array}{c}\text { Total of the Baltic } \\
\text { region }\end{array}$ & 833 & 1013 & 827 & 828 & 815 & 737 & $-11 \%$ \\
\hline Total of the world & 16260 & 18980 & 16210 & 16830 & 20700 & 15430 & $-5 \%$ \\
\hline
\end{tabular}

Table 2. Export volume of food products from Russian Federation.

\begin{tabular}{|c|c|c|c|c|c|c|c|}
\hline \multirow{2}{*}{ Country } & \multicolumn{9}{|c|}{ Import, mIn. \$ US } & $\begin{array}{c}\text { The change in } \\
\text { the volume of } \\
\text { import 2018 / } \\
\mathbf{n y y y y y y y}\end{array}$ & $\mathbf{2 0 1 3}$ & $\mathbf{2 0 1 4}$ & $\mathbf{2 0 1 5}$ & $\mathbf{2 0 1 6}$ & $\mathbf{2 0 1 7}$ & $\mathbf{2 0 1 8}$ years \\
\hline Denmark & 945 & 387 & 130 & 129 & 173 & 117 & $-88 \%$ \\
\hline Germany & 1997 & 1521 & 964 & 987 & 1225 & 883 & $-56 \%$ \\
\hline Estonia & 119 & 67 & 22 & 19 & 23 & 16 & $-86 \%$ \\
\hline Lithuania & 414 & 312 & 73 & 72 & 86 & 59 & $-86 \%$ \\
\hline Latvia & 160 & 158 & 67 & 26 & 41 & 31 & $-81 \%$ \\
\hline Poland & 1625 & 1159 & 414 & 371 & 425 & 289 & $-82 \%$ \\
\hline Finland & 561 & 414 & 116 & 104 & 122 & 79 & $-86 \%$ \\
\hline Sweden & 154 & 151 & 88 & 94 & 122 & 75 & $-51 \%$ \\
\hline $\begin{array}{c}\text { Total of the } \\
\text { Baltic region }\end{array}$ & 5975 & 4169 & 1875 & 1803 & 2217 & 1550 & $-74 \%$ \\
\hline $\begin{array}{c}\text { Total of the } \\
\text { world }\end{array}$ & 43340 & 39940 & 26650 & 24720 & 28880 & 19463 & $-55 \%$ \\
\hline
\end{tabular}

used data that are freely available on the official website of the Federal Customs Service [11].

The Baltic "line" of the Russian food trade is illustrated by the following general figures. In 2018, the share of food imports to the Russian Federation from other countries in the Baltic region was about $8 \%$ of its total imports. The share of total exports of food products to the countries of the region was about $4.78 \%$ of Russia's total exports. For comparison, in general, the share of all countries of the Baltic region in the USSR's foreign trade in the last years of its existence was about $29 \%$. The explanation of such a significant decline in the volume of trade is seen in the current processes of globalization and transformation of foreign trade relations due to the exacerbation of the geopolitical situation.

The downward trend in Russia's foreign trade turnover with the countries of the region in terms of food products during 2013-2018 clearly illustrated by the data Table 1, 2. For sure, it is largely due to the response of Russia to sanctions and the sharp fall in the ruble exchange rate in 2015.

Important detail is that the decline in export and import of Russia with the countries of Baltic region significantly exceeds the decline in food turnover with the rest of the world, which indicates a serious deterioration in trade relations between Russia with countries this region.

The graph (Fig. 1) shows the dynamics of import of the main groups of food products for the period from 2013 to 2018. It is not difficult to see that the sharp decline in the volume of goods imported from the countries of the Baltic region begins in 2014, which is caused by a sharp change in the geopolitical situation in Europe and, above all, by events in Ukraine. (Relatively stable value is preserved in the import of cereals, however, in terms of value, this indicator, like all others, is small).

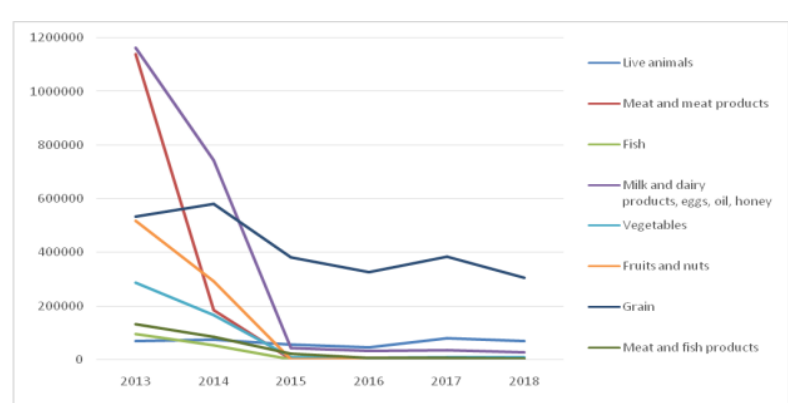

Fig. 1. Import of the main groups of food products to Russia from Baltic region, thousand US dollars (Source: compiled by the author according to the Federal Customs Service [11]). 
In response to sanctions in August 2014, Government Decree № 778 [1] introduced a ban on the import of agricultural products, raw materials and food, including from the countries of the European Union, and also includes all countries of the Baltic region, with the exception of the Russian Federation. This restriction applies to all major food products analyzed in this paper, except for cereals, which, by the way, explains the relative stability of this indicator in the foreign trade of countries.

In 2013, Poland, Germany and Denmark were the leaders in terms of food supplies to Russia. Nowadays, shipments from these countries are minimized. (Fig. 2).

To identify the factors explaining these trends, a more detailed analysis of the import structure of the countries listed above is needed. If we do not deal with the problems of food consumption at the global level (where they are largely due to the decisions of international organizations and specialized bodies FAO, WTO, etc.), then at the subregional level we are interested in many issues of food trade depend on programs and projects adopted by integration unions. In our case, the typical thing of this kind is the European Union, which concludes and controls intergovernmental agreements on the solidarity behavior of states in the areas of trade, pricing, product standardization, quality parameters, etc. Therefore, the nature of many indicators appearing in the tables and figures is due to EU policy.

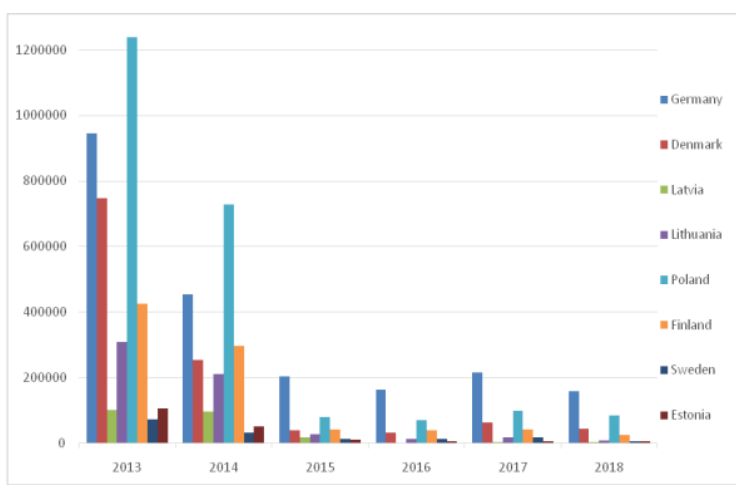

Fig. 2. The volume of imports to Russia from the Baltic region, thousand US dollars (Source: compiled by the author according to the Federal Customs Service [11]).

The structure of food supplied to the Russian market has also undergone significant transformation. Consider the changes on the example of these "pre-sanctioned" leaders.

Of course, the volume and nature of trade exchange strongly depends on bilateral interstate relations. Foreign trade relations with Poland have always been difficult. As a result of the introduction of economic sanctions against Russia and the reciprocal food embargo, Poland has taken a number of measures to find new markets for its products. At the moment, the mutual foreign trade relations of the Russian Federation and Poland have undergone very significant changes.

The main groups of Polish food products supplied to Russia in 2013-2014 there were fruits and vegetables, products of animal origin, meat and meat products goods currently included in the list of prohibited for import to Russia. Currently, the main type of goods imported from Poland is products from cereals and flour (Fig.3).

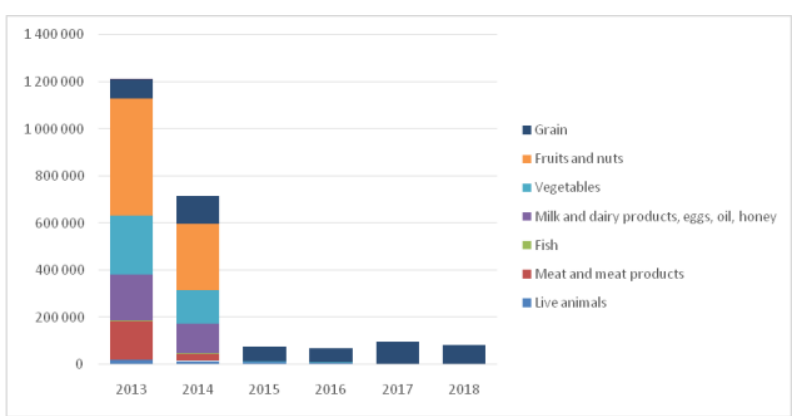

Fig. 3. Food Imports from Poland to Russia, US\$ (Source: compiled by the author according to the Federal Customs Service [9]).

Similarly, the ban on the importation of food products from Denmark has an impact. The change in the structure and volumes of imported food from Denmark is presented in Fig. 4.

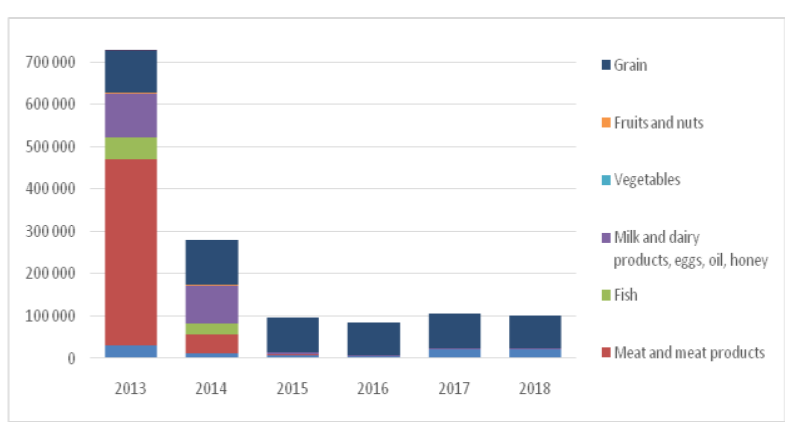

Fig. 4. Import from Denmark to Russia, US \$ (Source: compiled by the author according to the Federal Customs Service [11]).

If in 2013 the main item of imports from this country was meat and meat products, in 2014 there was a sharp decline in its total absence in 2018. The second largest group until 2015 was milk and animal products, which also dropped sharply in after the introduction of the embargo. As in the case of imports from Poland, the volume of delivered products from flour and cereals remained relatively stable.

A significant reduction in the volume and range of food products is demonstrated by the import of Germany. The import structure is presented in Fig. 5.

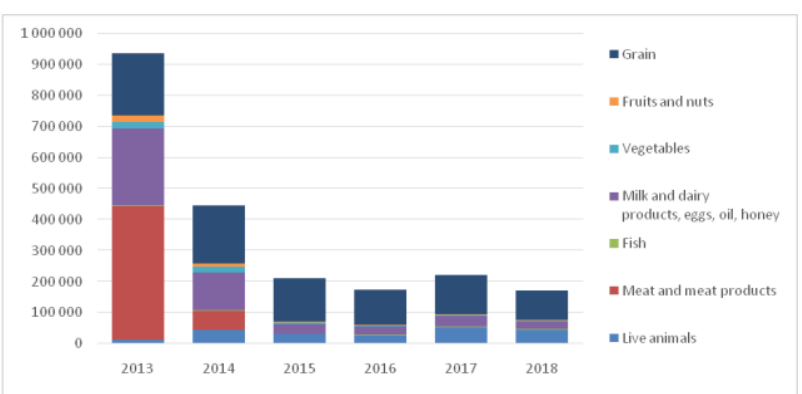

Fig. 5. Import of food products from Germany to Russia, US \$ (Source: compiled by the author according to the Federal Customs Service [11]). 
As in the countries discussed above, in the structure of imports from Germany, the most stable volumes differ in the supply of products from flour and cereals. Food products such as milk, eggs, cheese, butter, meat and meat products show the greatest reductions.

It is necessary to point out that European food products inspire the confidence of Russian buyers, this can also be attributed to the important competitive advantage. So, as a result of our research [5, 6], conducted in the regions of the North-West Federal District, about $60 \%$ of consumers are ready to do this solely in relation to European products if they decide to purchase imported food. Although European products, as a rule, are not unique (for example, there is a large selection of dairy and fermented milk products from various manufacturers on the market), they have taken trust of Russian consumers for their quality, stability, and history of the demand.

In contrast, imports, the structure of exports of food products from Russia to other countries of the Baltic region is more stable and is shown in Fig. 6. It is obvious that the largest volumes of export deliveries were to Latvia, Lithuania and Germany.

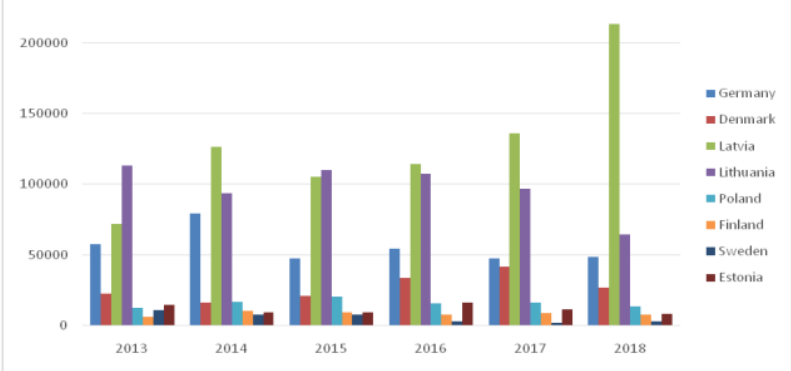

Fig. 6. The volume of exports from Russia to the countries of the Baltic region, thousand US dollars (Source: compiled by the author according to the Federal Customs Service [11]).

The leader in the procurement of Russian food products is Latvia: for the period from 2013 to 2018. The volume of exported products increased almost threefold. In the Figure 7 presents the dynamics of exports of the main groups of food products to Latvia. Mainly grain crops are exported from Russia to this country. Latvia is among the three countries leading in the procurement of Russian grain (along with Egypt and Turkey). In addition, the Baltic countries transit Russian grain, which is expensive or difficult to export through the ports of the South and North-West Russia, because there is not a single specialized grain terminal in the NorthWest of Russia that could handle transshipment. Other groups of foodstuffs exported to Latvia are fats and oils, fruits and vegetables.

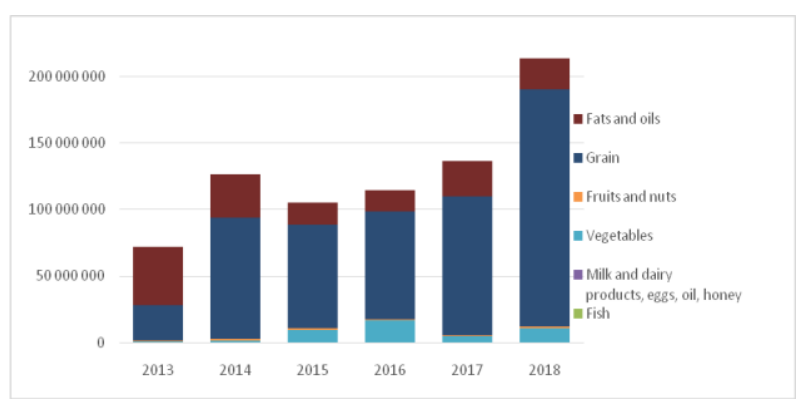

Fig. 7. The volume of exports from Russia to the countries of the Baltic region, thousand US dollars (Source: compiled by the author according to the Federal Customs Service [11]).

It should be noted that during 2013-2018. the share of cereals in total exports of food products increased from $33 \%$ to $83 \%$. This indicates a certain success of Russia in the production of these agricultural products. In addition, the growth rate and geography of deliveries of grain and its products are increasing.

The second country in terms of exports of Russian food and raw materials for its production at the moment is Lithuania. The structure of goods exported from Russia to Lithuania is presented in Fig. 8.

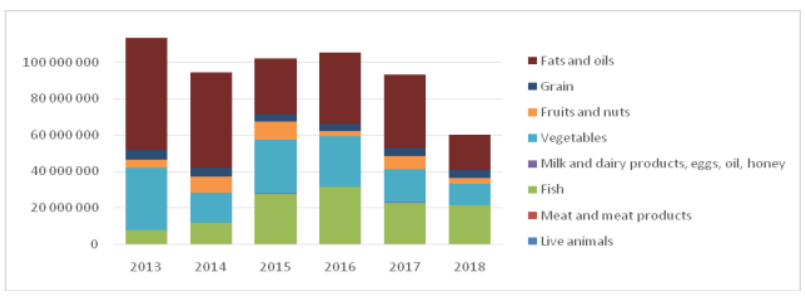

Fig. 8. Export from Russia to Latvia, \$ USA (Source: compiled by the author according to the Federal Customs Service [11]).

The largest decline in exports to Lithuania was due to two food groups: fats and oils and vegetables. Increased supply of fish.

The main types of food products exported from Russia to Germany (Fig.9) are cereals, fats and oils, as well as fish. Only in two positions there is an increase in exports (compared with 2013) - for the supply of fish and vegetables.

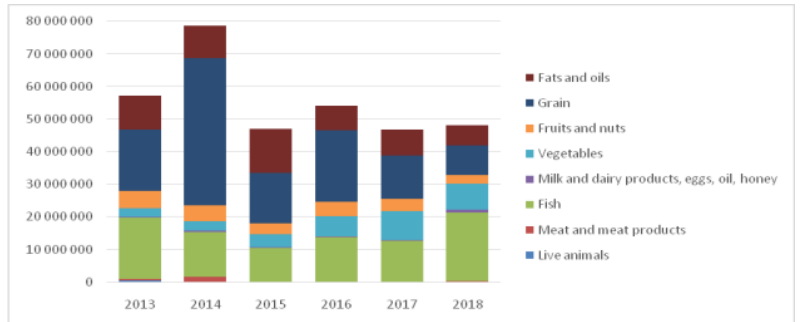

Fig. 9. Export from Russia to Lithuania, US \$ (Source: compiled by the author according to the Federal Customs Service [11]).

\section{Conclusion}

A method for the disposal of residual biomass of the The analysis of agricultural trade in the Baltic region shows that the place and role of Russia in the current situation 
is influenced by fundamental changes in the international arena due to the globalization of economic activity. The effect of the imposed sanctions regimes affects both the EU and the Russian Federation. In addition, it is necessary to take into account the successes in selfsufficiency in food of the EU countries and the tendency to reduce the share of the agrarian sector in the world product.

The trade and transport and logistics development of the North-West, as one of the "supporting regions" of Russia, is considered in the context of the accelerated integration of the country into the global market. The growth of the trade balance with the countries of the Baltic region can strengthen the functions of the NorthWest as a national "window-adapter" to the global market and the developer in relation to the rest of the country. Unfortunately, the real facts show many difficulties and contradictions in the development of trade relations. The analysis of changes in the export and import of food and agricultural products allowed us to show the scale of negative phenomena in the trade and economic relations of the Russian Federation and other countries of the Baltic region.

The fact is that there are negative phenomena in the trade and economic relations of the Russian Federation with the countries of the Baltic region, including the low level of variation in the volume and structure of goods imported and exported from the Baltic countries. The direction of changes and their dynamics depend both on the transformation of market conditions and on the reaction of individual market participants and the states they represent. There are three key groups of strategies currently implemented by food exporters to Russia [6]:

1. Changes in the policy of supporting producers of agricultural products and food products with a shift in emphasis on supporting the production of exportpotential products that are not included in the sanctions list established by the Russian Government or the components used to produce "sanctioned" food products in Russia.

2. The development of non-price factors that increase the competitiveness of European food products on the Russian market;

3. Search for legal "loopholes" to circumvent the prohibitions and restrictions imposed by the Government of Russia (the latter, in fact, is tactical rather than strategic in nature).

Unfortunately, the relative stationary number for the period from 2015 to 2018 indicates the presence of any positive changes and the establishment of foreign trade relations in the Russian Federation with the countries of the Baltic region. At the same time, it is necessary to express the hope that a crisis period in relations will pass, and as many centuries ago partners of the Hanseatic League, modern countries will be able to establish a dialogue and intensify mutually beneficial trade relations.

\section{References}

[1] Resolution of the Government of the Russian Federation of 07.08.2014, no. 778 (ed. From 11.26.2018), "On measures to implement the decrees of the President of the Russian Federation" of 6 August 2014, no. 560, of 24 June 2015, no. 320, from 29 June 2016, no. 305, dated 30 June 2017, no. 293, dated 12 July 2018, no. 420".

[2] Yu. Gladky, S. Kornekova, Import substitution and competitiveness of the Russian economy: to the dialectics of interconnections, Society. Wednesday. Development, 3, 92-97 (2015).

[3] S. Kornekova, Food consumption geography: system analysis, Monograph, SPb.: SPbESU publishing house, 242 (2017).

[4] S. Kornekova, On food security of the population of countries and regions, News of St. Petersburg State University of Economics, 4, 96-102 (2017).

[5] S. Kornekova, E. Kumerdank, Estonian food products on the market of St. Petersburg, Strategy for the Development of an Innovative Economy, Materials of the scientific-practical conference of young scientists and students, held in the framework of the II Eurasian Youth Forum, Dialogue of Civilizations, The Way to the North, 29-30 April 2011, Tallinn, 215-216 (2011).

[6] S. Kornekova, O. Kulikova, Volatility of the structure of Russian food imports under the influence of the anti-sanction policy, Vestnik of Tver State University, A series of economics and management, 3, 49-56 (2016).

[7] S. Kornekova, L. Khamchieva, Consumer baskets of European countries: significance and approaches to formation, Bulletin of Tver State University. Series: geography and geoecology, Tver: TvGU publishing house, 2, 156-160 (2016).

[8] S. Kornekova, O. Kulikova, On the dynamics of consumer goods of the Russian Federation from EU countries: 2012-2015, Science and business: ways of development, 5, 39-43 (2017).

[9] I. Maksimtsev, A. Koroleva, N. Orphan, The state and prospects of trade and economic cooperation between Russia and the European Union in the Baltic Sea region, Monograph, SPb.: SPbGEU Publishing House, 170 (2016).

[10] N. Mezhevich, Problems and Prospects of Economic Relations between Russia and the Baltic States in the Conditions of Sanctions Regimes, Russian Association for Baltic Studies, 2, 4, 64 (2017).

[11] Official website of the Federal Customs Service (FCS) [Electronic resource]. Available at: http://www.customs.ru/.

[12] G. Fedorov, Yu. Zverev, V. Korneevets, Russia in the Baltic: 1990-2012, Monograph, SPb.: Immanuel Kant Baltic Federal University Publishing House, Kaliningrad, 252 (2013).

[13] P. Jackson, N. Thrift, Geographies of consumption, Acknowledging consumption, Routledge, London, (1995). 
[14] A. Kelly, W. Becker, E. Helsing, Food balance sheets, Food and health data: their use in nutrition policy making, World Health Organization, Copenhagen (1991).

[15] J. Mansvelt, Geographies of Consumption London, The Cromwell Press Ltd., Trowbridge, Wiltshire, 209 (2005). 